\title{
Tidal exchange, bivalve grazing, and patterns of primary production in Willapa Bay, Washington, USA
}

\author{
N. S. Banas ${ }^{1, *}$, B. M. Hickey ${ }^{1}$, J. A. Newton ${ }^{2}$, J. L. Ruesink ${ }^{3}$ \\ ${ }^{1}$ School of Oceanography, Box 355351, ${ }^{2}$ Applied Physics Laboratory, Box 355640, and ${ }^{3}$ Department of Biology, Box 351800, \\ University of Washington, Seattle, Washington 98195, USA
}

\begin{abstract}
Willapa Bay, Washington, USA, is a shallow, coastal-plain, upwelling-influenced estuary where Pacific oysters Crassostrea gigas are intensively cultivated. CTD transect data show that in the long-term average over the May to September growing season, Willapa Bay is a sink for oceanic phytoplankton, not a net exporter: as the tidal circulation stirs ocean water into the estuary, chlorophyll concentration declines by 30 to $60 \%$ relative to a hypothetical dilution of the ocean end-member. A 3D circulation model (General Estuarine Transport Model, GETM) was modified to include a phytoplankton-like tracer subject to variable intertidal benthic grazing rates. The grazing rate that best reproduces the along-estuary phytoplankton biomass profile agrees, within confidence limits, with an estimate of cultivated-oyster filtration from literature values. Oysters and other intertidal benthic grazers may thus be the primary cause of the net loss of phytoplankton within the estuary in summer. These grazers appear to be within a small factor of their carrying capacity: as bay-total filtration capacity is increased in the model, the chlorophyll intrusion shortens and food intake per individual grazer declines. Nevertheless, only 8 to $15 \%$ of the net tidal supply of oceanic phytoplankton is consumed within the estuary. Even in this well-flushed system, the small-scale structure of tidal transport-rather than total oceanic supply — controls overall food availability for the benthos.
\end{abstract}

KEY WORDS: Estuaries · Primary production · Bivalves · Tidal circulation · Biophysical interactions · Willapa Bay

Resale or republication not permitted without written consent of the publisher

\section{INTRODUCTION}

Willapa Bay, Washington (Fig. 1), is a shallow, coastal-plain estuary on the northwest Pacific coast of the USA where Pacific oysters Crassostrea gigas are intensively cultivated: $~ 9 \%$ of US commerical oysters are grown there (Ruesink et al. 2006). In contrast to the majority of temperate estuaries (Heip et al. 1995), both primary production (Newton \& Horner 2003) and oyster production in general (Ruesink et al. 2003) are highest near the mouth and decline up-estuary, rather than the reverse. The purpose of the present study was to determine the physical and biological controls that establish these strong gradients. This study synthesizes results from 10 years of Washington SeaGrantsupported research in Willapa Bay that has aimed to establish the links between coastal ocean dynamics, estuarine circulation, primary production, and sec- ondary production in Willapa Bay and the other small coastal-plain estuaries of Washington and Oregon. At the same time, this study is motivated by the more general question of how benthic filter feeders can limit and be limited by phytoplankton production in shallow estuaries (Cloern 1982, Peterson \& Black 1987, Dame \& Prins 1998).

\section{Coastal upwelling and primary productivity}

Willapa Bay experiences large tides compared with estuaries on other coasts of the USA: more than $50 \%$ of the surface area and volume of the bay lies in the intertidal zone, as is common among the small, coastal-plain estuaries of the northwest Pacific (Hickey \& Banas 2003). Tides are mixed-semidiurnal, and the range from mean higher high water (MHHW) 


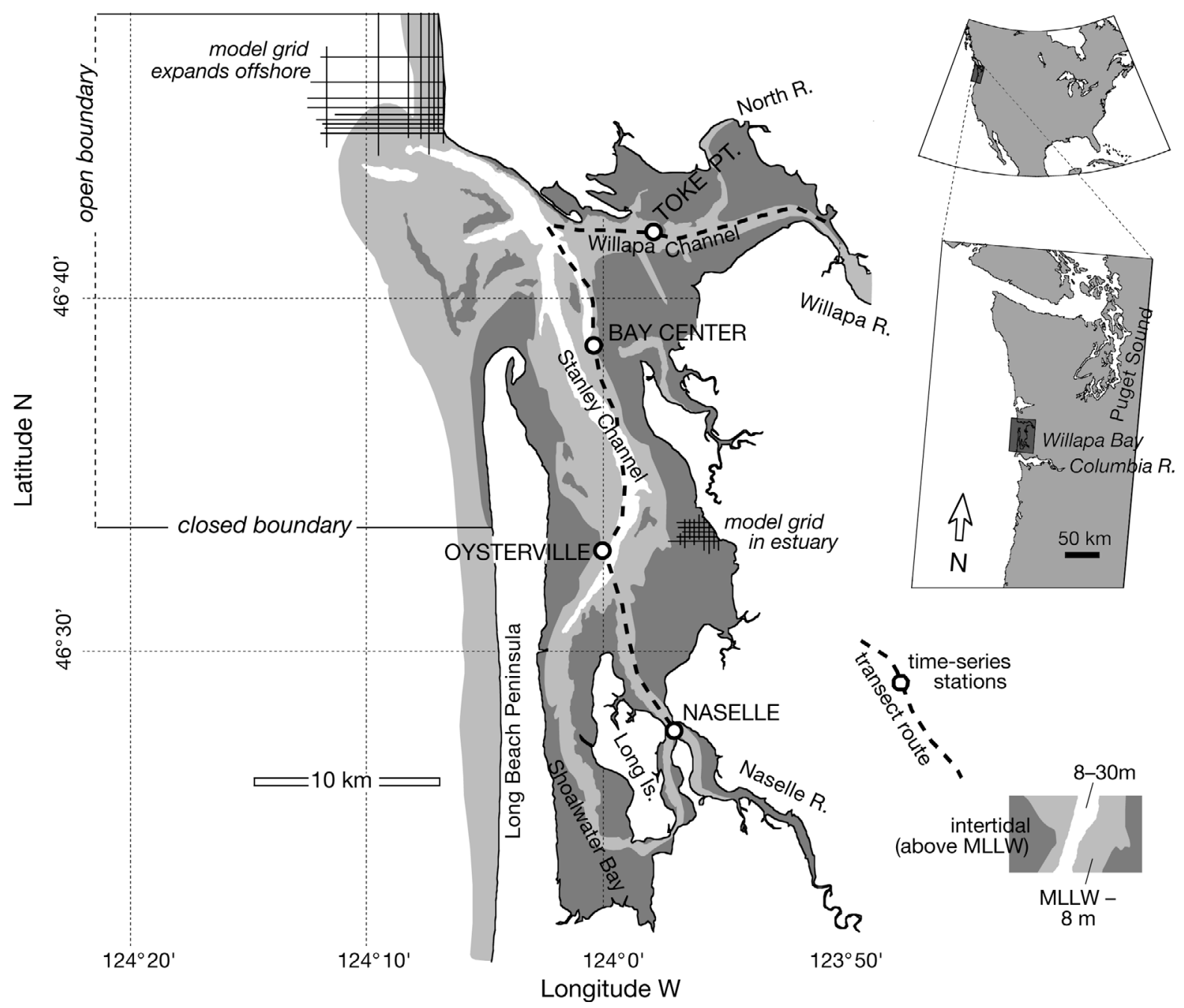

Fig. 1. Willapa Bay, Washington, USA, with CTD transect route (dashed line), time-series stations (O), and model grid indicated

to mean lower low water (MLLW) is $\sim 3.5 \mathrm{~m}$. River input into these estuaries (with the dramatic exception of the Columbia River, immediately south of Willapa Bay; Fig. 1) and ocean water properties are both highly correlated with mesoscale $(\sim 500 \mathrm{~km})$ atmospheric forcing, both seasonally and on the event ( 2 to 10 d) scale. Southward large-scale winds, which predominate in summer and during breaks of fair weather in winter, drive coastal upwelling, which brings cold, salty, nutrient-rich water to the surface and into the estuaries (Hickey 1989, Landry et al. 1989, Hickey \& Banas 2003). Coastal phytoplankton blooms also advect directly into the estuaries during upwelling conditions (Roegner \& Shanks 2001, Roegner et al. 2002). During winter and foul-weather events in other seasons, northward large-scale winds drive coastal downwelling, during which surface waters are warmer, fresher, and nutrient- and biomass-depleted.
Riverflow and terrestrial nutrient input are close to zero in Willapa Bay for much of the summer growing season; however, river nutrients may be locally important near the river mouths in winter and spring (Ruesink et al. 2003). As a result, in summer, Willapa Bay is dynamically more like an unstratified, riverless tidal lagoon than a partially mixed estuary (Banas et al. 2004). Coastal upwelling is the predominant nutrient source, and horizontal transport (the net circulation that stirs ocean water into the bay's interior) is the primary physical control on production, on both event (2 to $10 \mathrm{~d}$ ) and seasonal timescales (Newton \& Horner 2003, Ruesink et al. 2003, Banas et al. 2004, Banas 2005).

Newton \& Horner (2003) found that both phytoplankton biomass and primary productivity decline sharply from mouth to head, a fact documented further below. In addition, they found that among phytoplankton indicator species, oceanic species dominated consistently during high-primary-productivity periods 
(>3000 $\mathrm{mg} \mathrm{C} \mathrm{m}^{-2} \mathrm{~d}^{-1}$ ), and during many lower-productivity periods as well. However, no study has yet determined whether these patterns indicate the direct import of fully developed oceanic blooms, or in situ production from oceanic seed stock.

\section{Tidal flushing and transport pathways}

Because the supply of new ocean water is central to Willapa Bay's ecology, the dynamics of ocean-estuary exchange are as well. Recent observational and modeling studies (Banas et al. 2004, Banas \& Hickey 2005) have established that for most of spring and summer, horizontal tidal stirring is Willapa Bay's primary flushing mechanism. The classical river-driven, 2-layer 'estuarine' or 'gravitational' circulation (Pritchard 1956, Hansen \& Rattray 1966) accounts for less than $25 \%$ of spring-and-summer exchange. Willapa Bay's tidalresidual currents, which can be thought of as flood-ebb asymmetries in the tidal flow created by the complex channel geometry (Zimmerman 1986, Banas \& Hickey 2005), are strong enough to stir new ocean water $20 \mathrm{~km}$ into Willapa Bay in a few days (Banas et al. 2004). However, the strength of tidal stirring drops off by a factor of 20 from mouth to head (Banas et al. 2004, Banas \& Hickey 2005). This gradient means that despite the fact that half the volume of the bay enters and leaves with every tide, and that $30 \%$ of this intertidal volume is replaced with new ocean water on every tide (Banas et al. 2004), average water ages in the landward reach of the estuary are 3 to $5 \mathrm{wk}$ (Fig. 2).

This along-channel increase in water age is not linear. Model results indicate a local gap ('tidal dispersion gap') at mid-estuary, across which the circulation exchanges water only slowly (Banas \& Hickey 2005). A typical water parcel south of the gap may have spent weeks longer in the estuary than a typical parcel just 3 to $5 \mathrm{~km}$ away to the north of it (Fig. 2). This result corresponds closely to a phenomenon long known anecdotally in the Willapa Bay oyster industry: as Chapman \& Esveldt (1943) write,

It was well-known among the oystermen that if an imaginary line were drawn angling across Willapa Bay from the south quarter of the Nemah State Oyster Reserve on the east...to the west shore a mile or so south of Nahcotta that the best setting grounds would be south and east of this line and the best fattening and growing grounds would be north and west of it. This had been true with the Eastern oyster, true in considerable measure with the native oyster, and a brief survey showed it to be obvious with the Pacific oyster.

This imaginary line (Fig. 2) can thus be thought of as both a 'fattening line' - the southern limit of the best adult oyster growth conditions - and a 'recruitment line': Chapman \& Esveldt's (1943) comment about 'set-

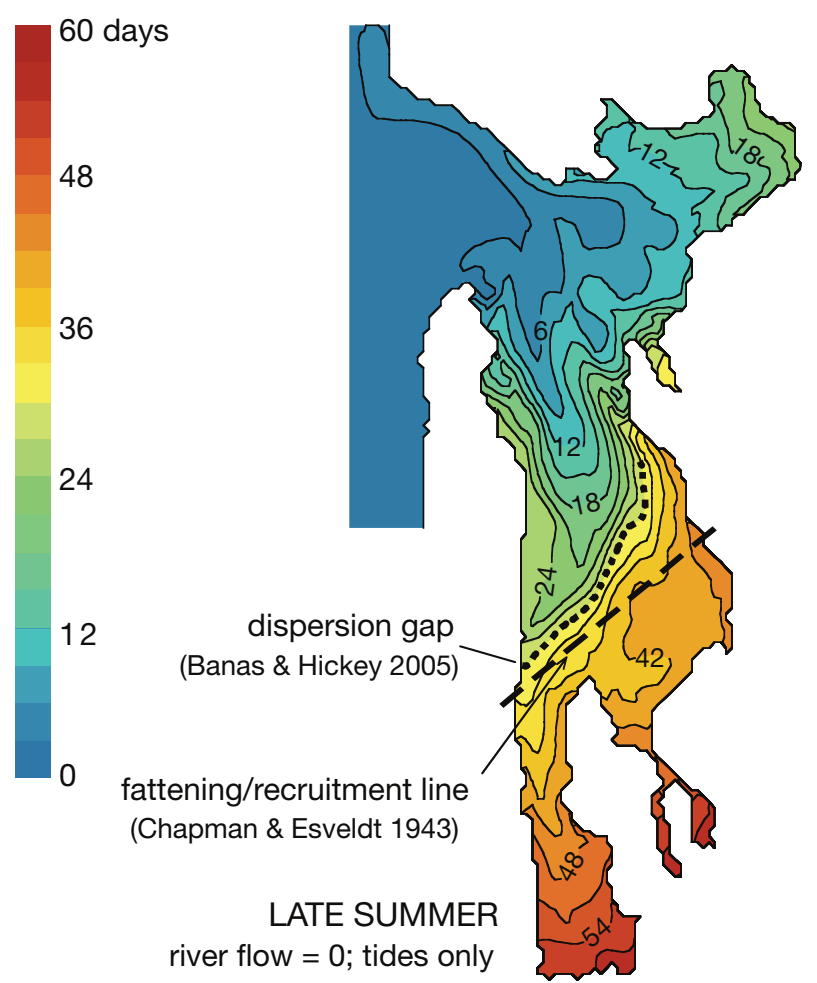

Fig. 2. Average water age (or time that each water parcel has spent in the estuary) in late summer, low river-flow conditions, from the circulation model of Banas \& Hickey (2005). The 'dispersion gap' (local minimum in horizontal tidal diffusivity) identified by Banas \& Hickey (2005) and the oyster fattening/recruitment line discussed by Chapman \& Esveldt (1943) are marked

ting grounds' refers to the fact that natural settlement of oyster larvae, which requires retention in the water column for 3 wk after spawning, occurs south of this line but not north of it.

\section{Patterns of oyster productivity}

Ruesink et al. (2003) found that this fattening line is part of a more general along-estuary gradient in oyster growth. With the exception of the productive beds along Willapa Channel (Fig. 1), which receives $80 \%$ of local river input and a higher load of terrigenous resources for oysters, seasonal oyster growth rate declines with distance from the mouth. This alongchannel variation is comparable with the lateral and vertical variation in growth through the intertidal zone (Ruesink et al. 2003).

Low growth rates in the southern bay are of particular concern because this region has been disproportionately affected by a long-term decline in oyster yields (Hedgpeth \& Obrebski 1981). Pacific oyster production in Willapa reached a peak in 1952 and then 
declined, levelling off in $\sim 1970$ at roughly one-third peak production (Feldman et al. 2000, Ruesink et al. 2006). Oyster beds in the south bay that at one time supported commercially viable growth rates no longer do, and have been largely abandoned. On the baywide scale, these long-term productivity changes may be related to climate-related changes in the northeast Pacific (Ebbesmeyer \& Strickland 1995, Schoener \& Tufts 1987, Whitney \& Welch 2002). On smaller scales, productivity may also be controlled by patterns of tidal advection, phytoplankton growth, and intra- and interspecies competition. Food competition among cultivated bivalves is well-known in other systems, on scales from individual $\sim 2 \mathrm{~m}$ mussel beds (Newell 1990) to the system level (Dame \& Prins 1998). In Willapa Bay, Hedgpeth \& Obrebski (1981) speculated that oysters near the mouth consume enough of the oceanic, upwelling-driven supply of phytoplankton to affect food concentration in the southern bay. Below we use a modified version of the Banas \& Hickey (2005) circulation model to test this idea.

\section{Overview}

The central questions of this study can be summarized as follows:

(1) What causes the mouth-to-head decline in summer phytoplankton biomass and productivity? Does this gradient primarily reflect (i) in situ blooms subject to variable local growth conditions, (ii) imported blooms whose extent is limited by the gradient in net tidal transport, or (iii) imported blooms controlled by grazing or other net losses within the estuary?

(2) What causes the mouth-to-head decline in oyster growth? Is there a corresponding gradient in food availability in intertidal areas? And if so, does this gradient reflect (i) food competition among oysters along the length of the bay (i.e. progressive draw-down of upwelling-derived phytoplankton), or (ii) the non-uniform strength of tidal stirring (i.e. a hydrodynamic, not biological, control)?

We show using time-series observations that in the broadest average, the answer to Question 1 is (iii). That is, in summer, Willapa Bay is a sink for upwellingfueled phytoplankton production, a net importer in which more phytoplankton biomass is consumed and transferred to higher trophic levels than is locally produced. To link this result to Question 2, we added a phytoplankton-like tracer to the Banas \& Hickey (2005) model, a tracer that is imported from the ocean and then removed by the benthos at an imposed rate. In biological terms this is a first-step back-of-theenvelope calculation even simpler than the 'bivalve carrying capacity' defined by Dame \& Prins (1998), but inclusion of the circulation in fine spatial detail makes the model, to borrow a phrase from Francis (2003), 'an envelope with a very large back'. We show that the answer to Question 2 is, counterintuitively, both (i) and (ii) simultaneously. Willapa Bay's oysters do compete for food on the bay-wide scale, in the sense that phytoplankton consumption in the outer estuary strongly controls phytoplankton availability in the upper estuary; but at the same time, the tidal circulation returns 85 to $92 \%$ of incoming oceanic phytoplankton to the ocean ungrazed.

\section{METHODS}

Observations of phytoplankton biomass and productivity. Transects down the main axis of the Willapa and Stanley Channels (Fig. 1) with a SeaBird 25 CTD were conducted monthly from autumn 1997 to autumn 2000. These transects provided spatially detailed (although instantaneous and tidally aliased) maps of salinity, temperature, chlorophyll, and dissolved oxygen: only the salinity and chlorophyll data are used in this study. During these transects, water samples were collected at 4 stations (Toke Point, Bay Center, Oysterville, and Naselle; Fig. 1) at 6 depths from the surface down to $1 \%$ surface light intensity, as estimated from Secchi depth. These samples were used to calculate depth-integrated chlorophyll biomass, production, and concentration of dissolved nutrients (nitrate, ammonium, phosphate, and silicate). Productivity was calculated through standard ${ }^{14} \mathrm{C}$-uptake experiments (Strickland \& Parsons 1968) with 24 h incubations; nutrient limitation was examined by adding excess nutrients (30 $\mu \mathrm{M}$ ammonium, $3 \mu \mathrm{M}$ phosphate) to duplicate surface samples within these productivity experiments. Details of sampling methods can be found in Newton \& Horner (2003).

It is not immediately clear that a given chlorophyll concentration indicates the same carbon-biomass concentration at every location in the estuary. In general, the carbon:chlorophyll $(\mathrm{C}: \mathrm{chl})$ ratio in marine phytoplankton varies with light intensity, temperature, level of nutrient limitation, and taxon, and ranges from 10 to 200 (Falkowski \& Raven 1997). Cloern et al. (1995), however, provide a fit to results from 12 other studies that allows one to estimate the $\mathrm{C}$ :chl ratio from temperature, light, and nutrient limitation. In Willapa Bay, depth-averaged light intensity does not appear to have a mean along-estuary trend: in the average of the full CTD-transect time series, Secchi depth decreases by a factor of 2 from mouth to head along Stanley Channel, but channel depth decreases proportionally. Nutrient limitation (measured as the ratio of productivity with added nutrients to productivity without) does vary 
weakly, from a May to September mean of 1.8 at Bay Center to 1.4 at Naselle, and mean summer surface temperature varies from $15^{\circ} \mathrm{C}$ at Bay Center to $18^{\circ} \mathrm{C}$ at Naselle. Using the formula of Cloern et al. (1995), at a given light level, these nutrient-limitation and temperature differences correspond to $\sim 50 \%$ variation in the C:chl ratio. Thus, a given chlorophyll concentration in the upper estuary may indicate up to $50 \%$ more carbon biomass than it does near the mouth. This is an upper limit: it is possible that Willapa Bay's circulation is rapid enough to keep cells from fully adapting to any particular local conditions. We did not use Cloern et al.'s (1995) formula to adjust biomass measurements systematically, but the $50 \%$ uncertainty associated with it is discussed where appropriate.

Numerical modeling. In addition to the observations described above, this study makes use of a 3D circulation model, modified to include a tracer representing chlorophyll subject to variable growth and grazing rates. Banas \& Hickey (2005) describe the circulation model in detail. The model is an implementation of GETM, a relatively new hydrodynamic model developed for systems like Willapa Bay where flow over complex topography and flooding and drying of intertidal areas are central (Burchard \& Bolding 2002, Stanev et al. 2003, Burchard et al. 2004, Stips et al. 2004). GETM is open-source and under continuing development (see www.bolding-burchard.com).

The model domain in our implementation for Willapa Bay is shown in Fig. 1. The coastal 'ocean' in our model is highly idealized, a semi-enclosed reservoir, open only to the west, with depth limited to $30 \mathrm{~m}$, and without any along-shelf currents. We have only included a coastal ocean so that tidal and external water-property forcing can be applied to the bay gently and smoothly; data for model validation are only available from the bay mouth landward (Banas \& Hickey 2005), and we confine our attention to the estuary itself. The model grid is $175 \times 82$ in the horizontal with 12 sigma levels in the vertical. The bay itself is covered by uniform squares $255.5 \mathrm{~m}$ on a side, though the grid spacing gradually expands to $6 \mathrm{~km}$ in the 'ocean'. Model bathymetry is adapted from a grid developed by the US Army Corps of Engineers Seattle District, who resurveyed most of the subtidal area of the bay in 1998 (Kraus 2000, Banas \& Hickey 2005).

The model scenarios examined in this study involve only tidal dynamics, but Banas \& Hickey (2005) also examined the effects of variable riverflow and ocean density forcing. To simplify the analysis, in the model we imposed an idealized, perfectly repeatable semidiurnal (M2) tide, with an amplitude of $\pm 1.2 \mathrm{~m}$ at the open ocean boundary. This amplitude was chosen to reproduce the long-term mean tidal range at Toke Point (Fig. 1). Banas \& Hickey (2005) showed that this idealized-tide scenario (run D in that previous study) is sufficient to reproduce the 20-fold along-estuary decrease in horizontal tidal dispersion (see 'Introduction') within confidence limits. Point-by-point errors in tidal velocities and cross-sectionally integrated transports are 3 to $20 \%$ (Banas \& Hickey 2005).

To simulate chlorophyll in the model, we modified the treatment of temperature in GETM: the changes required should be possible in almost any primitive equation circulation model. First, we removed references to temperature in GETM's calculation of density, so that 'temperature' has no effect on the circulation and can be treated as a generic passive tracer. Next, we added code to the tracer-advection routine so that at each timestep, in every grid cell, the-tracer-formerly-known-as-temperature is multiplied by a factor $1+\mu_{\text {tot }} \Delta t$, where $\mu_{\text {tot }}$ is an imposed population growth rate (see next subsection) and $\Delta t$ is the model timestep. In general, pelagic growth and grazing can be included in $\mu_{\text {tot, }}$ but in the runs described in this study, only benthic grazing is imposed: the rationale is given in the next section.

Primary production budget. In general, the conservation equation for depth-averaged chlorophyll concentration $(c)$ can be written:

$$
\frac{\partial c}{\partial t}=\operatorname{advection}+\mu_{\mathrm{tot}} C
$$

where advection represents the circulation (all processes that affect chlorophyll the same way they do a conserved tracer like salt) and $\mu_{\text {tot }}$ is the total phytoplankton population growth rate. Following Lucas et al. (1999) and others, we can write the balance of sources and sinks that constitute $\mu_{\text {tot }}$ as:

$$
\mu_{\text {tot }}=\mu_{\text {growth }}-\mu_{\text {zoop }}-\frac{\alpha}{h}
$$

where $\mu_{\text {growth }}$ is the phytoplankton-specific growth rate in the water column, similar to the productivity measured by a ${ }^{14} \mathrm{C}$ uptake experiment; $\mu_{\text {zoop }}$ represents zooplanktonic grazing and other losses within the water column; and the final term represents benthic grazing. $\alpha$ (benthic filtration rate) is expressed in units of $\mathrm{m} \mathrm{s}^{-1}$, i.e. $\mathrm{m}^{3}$ of water $\mathrm{m}^{-2}$ of bottom area $\mathrm{s}^{-1}$, and $h$ is water depth in $\mathrm{m}$. Losses to sinking and burial, which we have not included explicitly, are presumably minor in this shallow, macrotidal system.

In general $\mu_{\text {zoop }}$ can be measured by dilution experiments (Landry \& Hassett 1982) or estimated more coarsely from zooplankton standing stock (e.g. Cloern 1982), but neither sort of data is available for Willapa Bay. In some systems, one might start by guessing that $\mu_{\text {zoop }}$ is small, but a recent compilation of dilution experiments in coastal and estuarine waters has shown that microzooplankton grazing rates can be a signifi- 
cant proportion of phytoplankton growth rates $(\mathrm{n}=$ 278, average $=60 \%$ : Calbet \& Landry 2004). As a result, we cannot neglect $\mu_{\text {zoop }}$ a priori, cannot evaluate the full chlorophyll budget in Eq. (2) empirically, and do not attempt to simulate the full budget. Our model experiments consider only the idealized case in which $\mu_{\text {growth }}$ and $\mu_{\text {zoop }}$ balance, so that Eqs. (1) \& (2) reduce to:

$$
0=\operatorname{advection}-\left\langle\frac{\alpha}{h} c\right\rangle
$$

where triangular brackets denote the tidal cycle average. (Tides are the only time-varying forcing in this model.) Eq. (3) can be taken to represent a long-term summer average in Willapa Bay, if 3 key assumptions are made: (1) That benthic grazing represents a longterm loss of chlorophyll biomass from the water column; (2) That zooplanktonic grazing is, in constrast, completely regenerated (in a long enough average); (3) That in situ growth of phytoplankton on oceanic nutrients is small compared with the import of phytoplankton biomass itself. The first assumption is equivalent to asserting that the regenerated fraction of benthic grazing is relatively small compared with filter-feeder growth and biodeposition (Songsanjinda et al. 2000), or at least that the regenerated fraction is lost in the uncertainty in $\alpha$, which in our case is an uncertainty of a factor of 3 (see next subsection). On short timescales, the second assumption would make no biological sense (Evans \& Parslow 1985), and so we do not consider the time-dependent behavior of our model to be meaningful; only the model's long-term equilibrium behavior will be discussed. The third assumption is not an a priori statement but rather a key result from the observational analysis below.

The only source of phytoplankton in the model is tidal import from a steady oceanic reservoir; the only sink is benthic grazing in the intertidal zone ( $\alpha$ is set to 0 in subtidal areas for simplicity). This is, to be clear, not intended as a comprehensive model of the bay, but rather a tool for answering the question: can the interaction of tidal import and intertidal benthic grazing reproduce the mean summer chlorophyll pattern we observe, or must other mechanisms be invoked? Additionally, what does the model's response to changes in $\alpha$ tell us about food limitation and competition among benthic grazers?

Filtration capacity of cultivated oysters. To make sense of the results, we need to know what value of $\alpha$ we would expect a priori for Willapa Bay's intertidal zone. Very little data are available on standing stock, distribution, and filtration rate of Willapa Bay's intertidal grazers, and so this calculation is necessarily coarse (note that the final step will introduce an uncertainty of a factor of 3). Our approach was to first esti- mate the average standing-stock density of a cultivated bed, and then to multiply by an estimate of filtration rate per unit body weight from laboratory studies.

Average oyster bed density was calculated by 2 methods. First,

$$
\begin{aligned}
\operatorname{avg} \text { density } & =\frac{1}{\text { cultivated area }} \\
& \times \frac{\text { annual harvest }}{\text { fraction harvest annually }}
\end{aligned}
$$

Approximately $36 \mathrm{~km}^{2}$ of tidelands are 'intensively cultivated' (Burrowing Shrimp Committee 1992, Feldman et al. 2000); this is $\sim 30 \%$ of Willapa's intertidal area (Hickey \& Banas 2003). The annual harvest has been largely stable since the 1970s (Ruesink et al. 2006); the 1984-93 average reported by Feldman et al. (2000) is $1.7 \times 10^{6} \mathrm{~kg} \mathrm{yr}^{-1}$ (shucked wet weight). A typical oyster in Willapa is harvested at Age 3 and beds are in a 4 yr rotation (Dumbauld et al. 1996): one could imagine 4 beds at staggered times in the rotation with densities $[0,1 / 3 m, 2 / 3 m, m]$, where $m$ is the density of a mature, harvestable bed. (The simplifying assumption here that growth is approximately linear is borne out by recent observations; B. R. Dumbauld pers. comm.) This implies that the annual harvest $(m)$ represents approximately half the standing stock $(0+1 / 3 m+$ $2 / 3 m+m)$. Combining these values through Eq. (4) yields an average density of $94 \mathrm{~g} \mathrm{~m}^{-2}$ (shucked wet weight) over the 'intensively cultivated' area.

This is likely a low estimate of standing-stock density, since the bay-wide harvest is almost certainly under- and not over-reported; indeed, density estimates from other sources are uniformly higher. Several estimates of $m$ are $650 \mathrm{~g} \mathrm{~m}^{-2}$ (Dumbauld 1994), $450 \mathrm{~g} \mathrm{~m}^{-2}$ (Hedgpeth \& Obrebski 1981), 470 and $750 \mathrm{~g} \mathrm{~m}^{-2}$ (interviews with oyster growers, B. R. Dumbauld pers. comm.). Units have been converted to SI for clarity. Assuming as above that the average density is one-half the mature bed density, and averaging all 5 estimates, yields a final average density of $250 \pm 110 \mathrm{~g} \mathrm{~m}^{-2}$ (SD; shucked weight).

Powell et al. (1992) pooled results from a number of other bivalve-filtration studies to produce a best-fit curve that relates filtration rate (in $\mathrm{m}^{3} \mathrm{~s}^{-1}$ ) to individual size and temperature. Kobayashi et al. (1997) tuned this result for Crassostrea gigas and summertime temperatures in particular, and also provide formulas for converting between $C$. gigas length, wet weight, and dry weight. Rearranging these results yields a curve that gives filtration per unit body weight as a function of individual size; for a broad range of sizes (1 to $10 \mathrm{~g}$ wet weight), predicted filtration rate is within the range $0.4 \pm 0.1 \mathrm{l} \mathrm{h}^{-1} \mathrm{~g}^{-1}$ under laboratory conditions. Multiplying this value by the average bed density calculated above, and propagating the relative uncertainties quadratically, gives a summary estimate of the 
filtration rate $\alpha$ over cultivated $C$. gigas beds: $\alpha_{\text {cult oys }}=$ $3 \pm 1 \times 10^{-5} \mathrm{~m} \mathrm{~s}^{-1}\left(\mathrm{~m}^{3}\right.$ of water $\mathrm{m}^{-2}$ of benthos $\left.\mathrm{s}^{-1}\right)$. This value is consistent with point measurements over natural beds in Willapa Bay (G. C. Roegner pers. comm.).

The extrapolation from $\alpha_{\text {cult oys }}$ to an average $\alpha$ that we can apply uniformly to Willapa Bay's intertidal zone (ITZ) is the largest source of uncertainty. Cultivated oysters are not the only significant benthic filterers in Willapa Bay. Manila clams are also cultivated, but in much smaller numbers (Ruesink et al. 2006); feral Crassostrea gigas reefs are widespread in the south end of the bay, and Griffen et al. (2004) have found that communities associated with the burrowing shrimp Upogebia pugettensis may actually filter faster $\left(\mathrm{m}^{2}\right.$ for $\mathrm{m}^{2}$ ) than dense, cultivated oyster beds. To further complicate the issue, $C$. gigas are cultivated not just at intertidal but also at shallow subtidal elevations in some areas. No map of cultivated and non-cultivated filter feeders with sufficient detail to sort out these complications has appeared. Still, we can assume that evenly distributing Willapa Bay's cultivated oysters over the ITZ and neglecting all other grazers would underestimate $\alpha_{\text {ITZ; }}$ conversely, assuming every $\mathrm{m}^{2}$ of ITZ filters as rapidly as a cultivated oyster bed would give a high estimate. These bounds correspond to $\alpha_{\text {ITZ(empirical) }}=2 \pm 1 \times 10^{-5} \mathrm{~m} \mathrm{~s}^{-1}$, the empirical benchmark we use below.

\section{RESULTS}

\section{Phytoplankton biomass growth and loss: 3 cases}

An along-channel profile of vertically integrated chlorophyll biomass $(B)$, normalized to $B$ at Bay Center, and averaged over all May to September measurements, is shown in Fig. 3. By itself, this gradient does not tell us anything about how an oceanic plankton population changes as the tidal circulation stirs it into the estuary. The gradient in $B$ could reflect a phytoplankton population steadily declining under grazing pressure; or, conversely, a population increasing everywhere, but increasing more rapidly in the outer estuary; it could even reflect a steady-state planktonic population advected passively by a tidal circulation which itself has an along-channel gradient (see 'Introduction'). Banas et al. (2004) found that event-scale salinity fluctuations propagated quickly from the mouth to a point between Bay Center and Oysterville (20 $\mathrm{km}$ in $2 \mathrm{~d}$ ) and then slowed, penetrating only weakly as far as Naselle. Such an up-estuary decrease in penetration speed and amplitude would occur for any tracer whose ocean concentration fluctuates on the same 10 to $20 \mathrm{~d}$ scale as the time it takes tidal stirring to propagate those fluctuations upstream (this is the

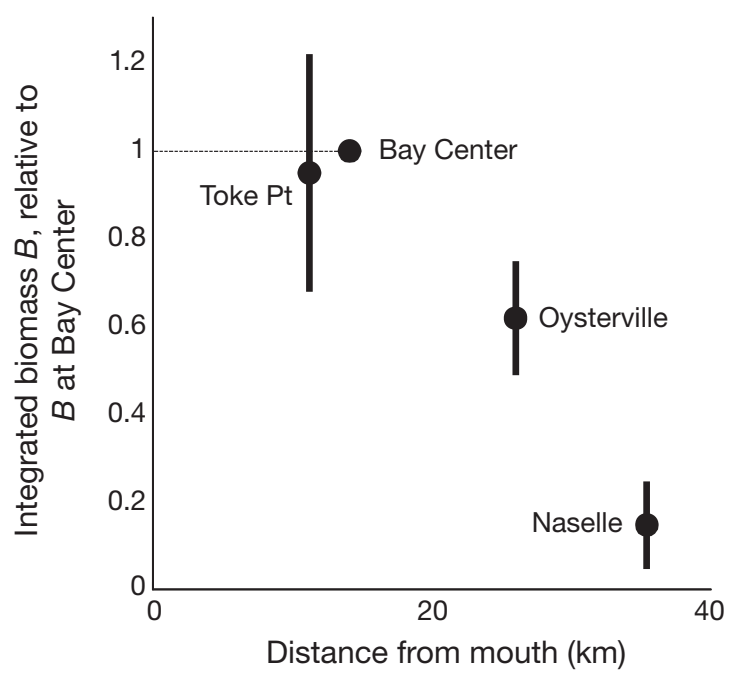

Fig. 3. Average summer (May to September) gradient in integrated chlorophyll biomass $B$ from seaward stations (Toke Point, Bay Center) to the river mouth at Naselle

classical 'oscillatory boundary layer' problem, Batchelor 1967, p. 353ff). To determine whether the gradient in $B$ is controlled by biological or simply circulational effects, we need to examine chlorophyll variations relative to a conserved tracer like salt.

Three snapshots of the chlorophyll-salinity relationship along Stanley Channel-results from CTD transects in July and September 1999 and February 2000 - are shown in Fig. 4. (We discuss these in detail, and then generalize to the full time series in the next subsection.) The July transect (Fig. 4b,e,h) took place during a strong upwelling event, during which salinity at Bay Center increased almost 5 psu in 6 d (Fig. 4a). As one would expect for strong upwelling conditions, chlorophyll in the July transect (Fig. 4e) is high near the mouth and declines toward the head of both Willapa Bay and Stanley Channel, consistent with the seasonal mean (Fig. 3). However, the highest chlorophyll concentrations do not coincide exactly with the highest salinities (>31 psu): the chlorophyll-salinity (chl-S) relationship along Stanley Channel is not monotonic, but rather has a peak near 29 psu (Fig. 4h). If the chlorophyll distribution were controlled only by mixing between static river and ocean end-members, this chl-S profile would be linear. The fact that the chl-S curve is lifted above the ocean-to-river mixing line means that either oceanic chlorophyll at the mouth has suddenly and recently decreased, or that chlorophyll is being created within the outer estuary. Indeed, it seems likely that just as oceanic blooms that begin at the coastal wall continue to grow as the upwelling circulation advects them offshore, so does the population advected into the estuary continue to increase, at least initially. 


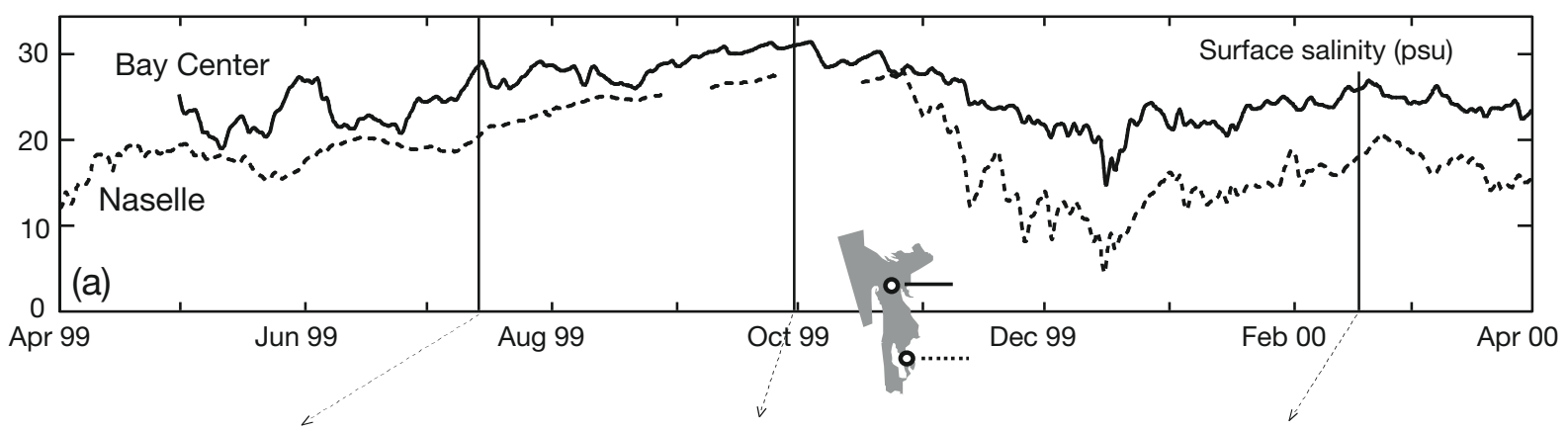

(b) Jul 14, 1999

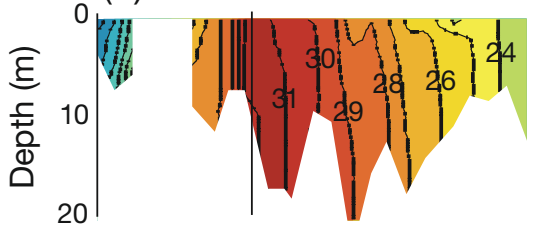

(e)

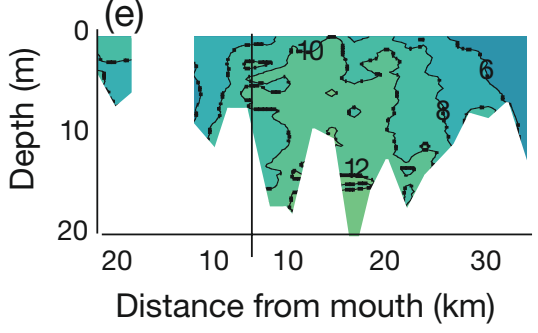

Distance from mouth $(\mathrm{km})$ (c) Sep 30, 1999

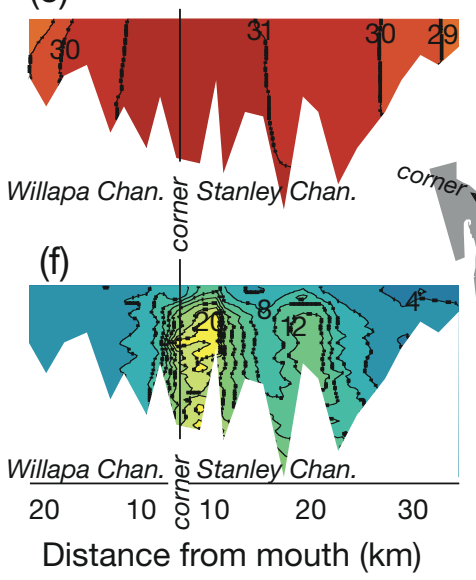

(d)
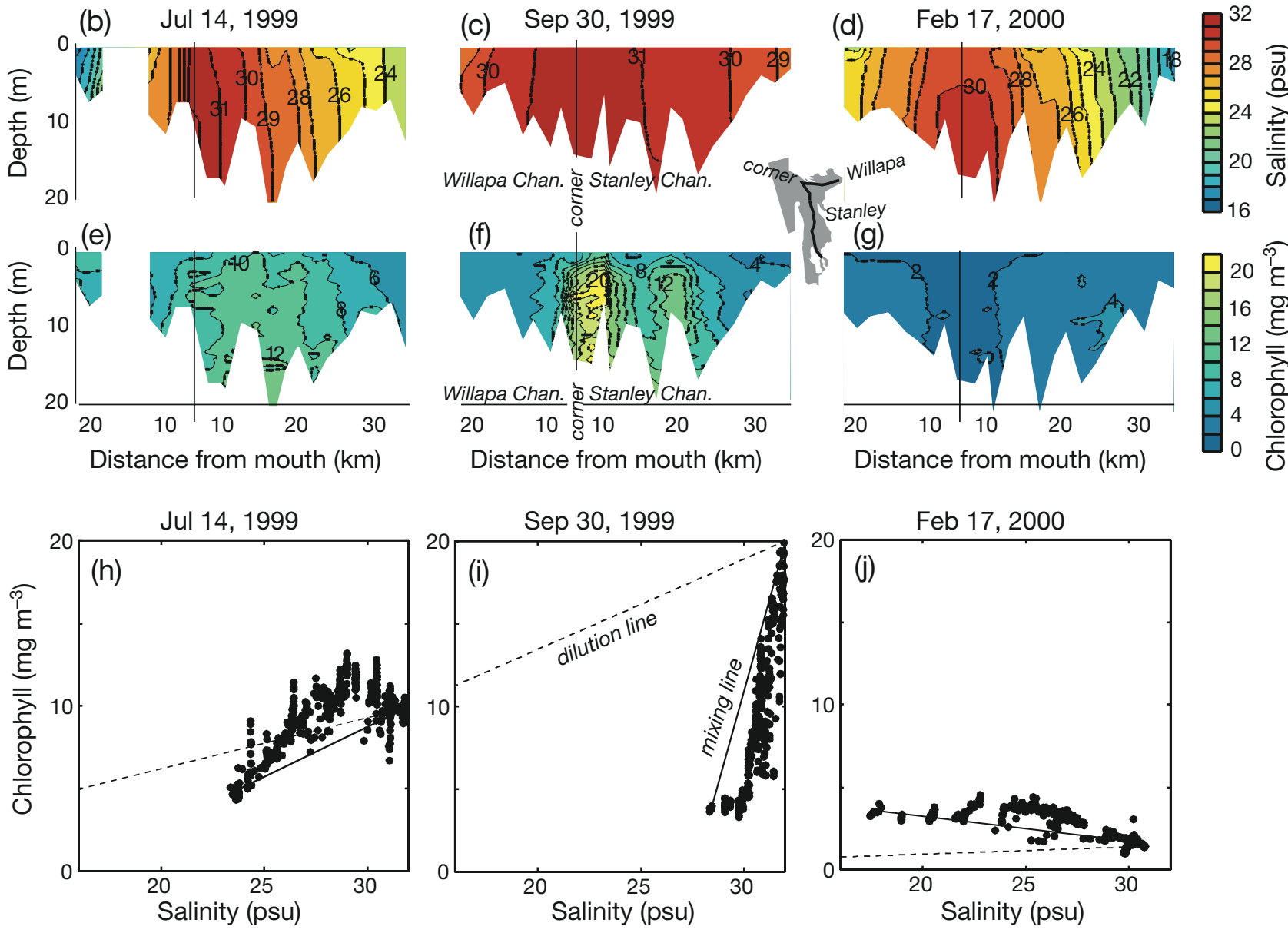

Fig. 4. (a) Time series of surface salinity over 1 yr at Bay Center and Naselle. (b-g) Instantaneous vertical sections of salinity and chlorophyll along the Willapa (northern) and Stanley (southern) Channels from CTD transects on 3 dates. The 'corner' at which the 2 channels intersect is the point closest to the ocean mouth. $(\mathrm{h}-\mathrm{j})$ Transect data replotted to show the chlorophyll-salinity relationship along Stanley Channel. Mixing lines (solid) between ocean and river end-members and dilution lines (dashed) from ocean end-members to $(0,0)$ are shown

The second transect in this series, from September 1999, was conducted near the end of a more-thanmonth-long period of almost uninterrupted upwelling (Fig. 4a; see also Banas et al. 2004, Fig. 3 for the associated wind time series). The estuary by this point in the summer is almost entirely oceanic: salinity is $29 \mathrm{psu}$ at the river mouths (Fig. 4a). As for the July transect, chlorophyll is highest in the outer estuary and de- creases toward the head, but now the chl-S profile (Fig. 4i) curves so that it falls below the head-to-mouth mixing line. Thus, there is a net loss of chlorophyll relative to salinity along the channel. Note that the landward end-member is relatively free to move in waterproperty space in response to processes within the estuary in summer, and so it is more comprehensive to compare the chl-S profile with the 'dilution line' run- 
ning from the ocean end-member to $(0,0)$. Relative to this hypothetical ocean-water dilution, by the end of the upwelling season (Fig. 4i) chlorophyll in Willapa Bay's interior is negligible: $\sim 4 \mathrm{mg} \mathrm{m}^{-3}$, compared with 15 to $20 \mathrm{mg} \mathrm{m}^{-3}$ on the dilution line. (One could also express this as $0.14 \mathrm{mg} \mathrm{m}^{-3}$ for every 1 psu of salinity, as opposed to 0.5 to $0.6 \mathrm{mg} \mathrm{m}^{-3}$ per psu at the mouth). This indicates a first-order net population loss.

Finally, a transect conducted in February 2000, when downwelling was predominant and riverflow moderate-to-high for several months (see Banas et al. 2004), shows an along-channel chlorophyll profile opposite to the upwelling-season pattern. Chlorophyll is $<5 \mathrm{mg}$ $\mathrm{m}^{-3}$ everywhere in Stanley Channel, but is lowest at the mouth and increases toward the rivers (Fig. 4g). Furthermore, the chl-S profile (Fig. 4j) lies above both the mixing and dilution lines, indicating growth within the estuary.

Results from these 3 transects have been discussed in detail in order to demonstrate the range of variability of population growth-loss patterns between winter and summer. In the next section we use the full transect time series from which these 3 examples were selected to determine which patterns represent the seasonal mean.

\section{Phytoplankton population growth and loss: the seasonal cycle}

For any chl-S transect like the 3 just discussed, a convenient index of the growth-loss balance within the estuary is:

$$
r=\frac{C_{\text {Oys }}}{C_{\text {oc dilution }}}-1
$$

where $c_{\text {Oys }}$ is vertical-mean chlorophyll concentration at Oysterville (Fig. 1) and $C_{\text {oc dilution }}$ is defined as:

$$
c_{\text {oc dilution }} \equiv \frac{S_{\mathrm{Oys}}}{S_{\mathrm{oc}}} C_{\mathrm{oc}}
$$

i.e. the chlorophyll concentration that would give the same chl-S ratio at Oysterville as seen at the mouth. ( $S_{\mathrm{oc}}$ and $C_{\mathrm{oc}}$ are oceanic salinity and chlorophyll concentration.) When the growth-loss parameter $r=0$, changes in chlorophyll reflect dilution only, and the plankton population is otherwise neutral. When $r<0$, chlorophyll biomass is lost (relative to dilution) within the reach from the mouth to Oysterville: $r=-1$ represents complete loss. When $r>0$, biomass is increasing within that reach: $r=1$ represents a population doubling between the mouth and Oysterville.

The seasonal cycle of $r$ is shown in Fig. 5a for the 3 yr monthly transect time series. The 3 transects discussed in the previous section are marked by arrows. Integrated productivity $P$ (in $\mathrm{mg} \mathrm{C} \mathrm{m}^{-2} \mathrm{~d}^{-1}$ ), the production:biomass ratio $(P: B)$ (in $\mathrm{mg} C \mathrm{mg} \mathrm{chl}^{-1} \mathrm{~d}^{-1}$ ), and nitrate concentration (in $\mu \mathrm{M}$ ) from monthly bottle measurements are shown for comparison (Fig. 5b-d). During winter, $r$ is generally positive, indicating net growth within the estuary, as for the February 2000 transect discussed above (Fig. 4). In absolute terms, however, winter production is low $\left(<1000 \mathrm{mg} \mathrm{C} \mathrm{m}^{-2}\right.$ $\mathrm{d}^{-1}$; Fig. 5b), presumably because of light-limitation. Excess nitrate in the water column (Fig. 5c) supports this idea. In contrast, productivity is high during the May to September growing season (up to $6000 \mathrm{mg} \mathrm{C}$ $\mathrm{m}^{-2} \mathrm{~d}^{-1}$ at Bay Center; Fig. 7b) but almost always nitrate-limited (concentrations $<1 \mu \mathrm{M}$; Fig. 7c). Only during 3 out of 13 May-September transects does growth exceed loss between the mouth and Oysterville $(r>0)$ as in the July 1999 transect (Fig. 4): during the other 10 transects, the net population change is negative, as during the September 1999 transect (Fig. 4). The May to September mean $F_{\text {May-Sep }}=-0.27 \pm 0.14$; however, during many individual events $r<-0.5$, indicating that $>50 \%$ of incoming oceanic chlorophyll has been lost between the mouth and Oysterville.

Rapid changes in ocean water properties - instances in which the ocean end-member sampled during a transect is substantially different from the ocean water mass stirred into the estuary over the previous 10 to $20 \mathrm{~d}$ - presumably also add noise to our estimates of $r$. Nevertheless, the key result that $F_{\text {May-Sep }}<0$ is insensitive to whether $r$ is evaluated at Oysterville or some other mid-to-upper estuary location. Furthermore, this mean summer population loss is greater than can be explained by along-channel variation in the $\mathrm{C}$ :chl ratio (see 'Methods').

For scaling purposes, we can associate values of $r$ with population growth rates $\mu_{\text {tot }}$ by assuming that the fraction change in chlorophyll that $r$ represents takes place over $20 \mathrm{~d}$, the difference in water age between Oysterville and the mouth (Fig. 2). That is:

$$
\frac{c_{\text {Oys }}}{C_{\text {oc dilution }}}=r+1 \approx \exp \left(\mu_{\text {tot }} \times 20 d\right)
$$

Approximate $\mu_{\text {tot }}$ values given by Eq. (7) are shown along the vertical axis in Fig. 7a. Note that on average, in summer, $\mu_{\text {growth, }}$ which can be estimated as the production:biomass $(P: B)$ ratio divided by the $C$ : chl ratio, is at least an order of magnitude larger than the population growth rate $\mu_{\text {tot, }}$ and of the opposite sign. (This is true even if we assume a very high C:chl ratio of 100.)

To summarize: the analysis of chl-S curves shown in Figs. 4 \& 5 suggests that in the summer average, direct import of oceanic biomass is more important than in situ primary production fueled by newly imported oceanic nutrients. Chlorophyll is normally highest in the most oceanic water sampled, and declines steadily 

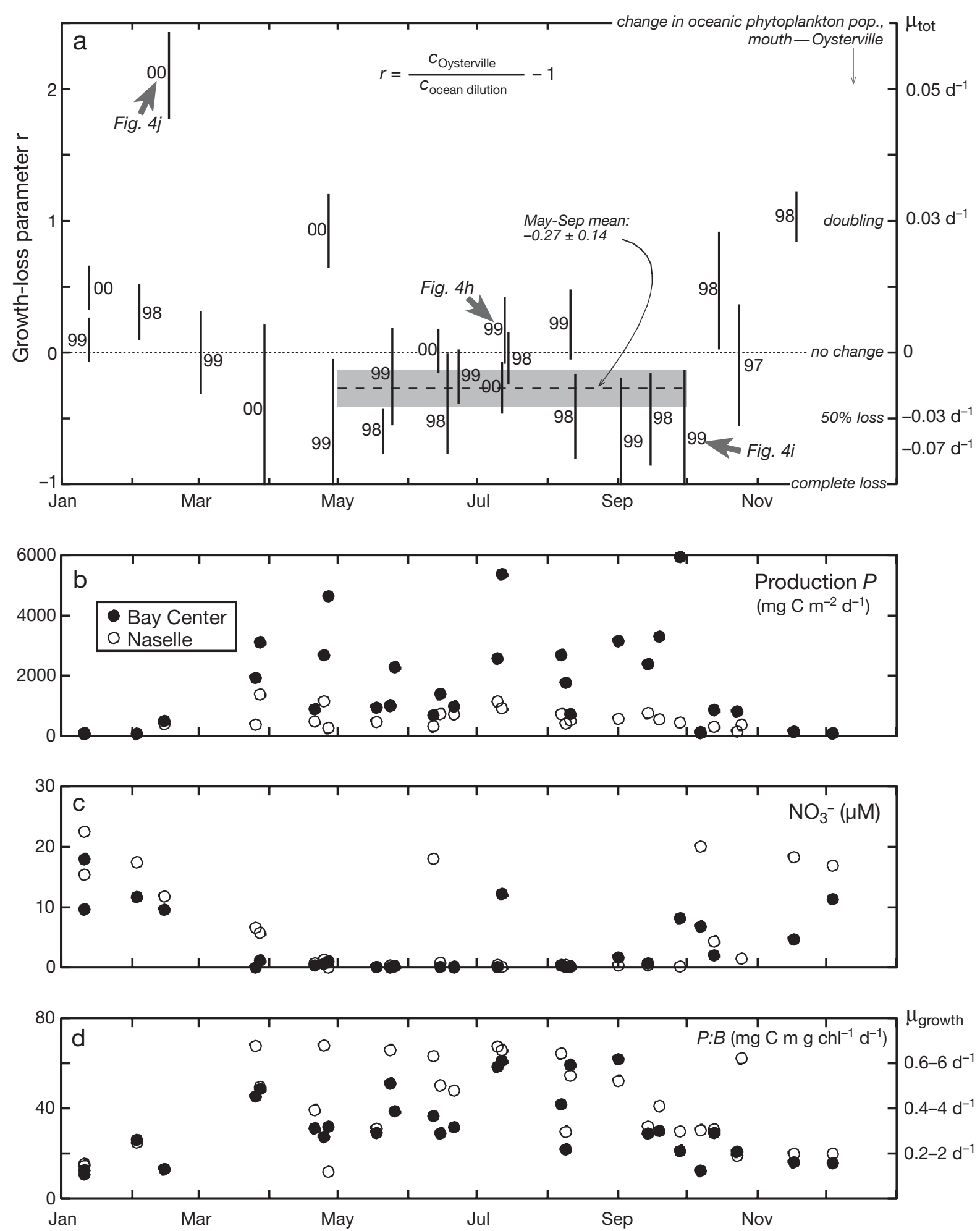

Fig. 5. (a) Seasonal variation in the growth-loss parameter $r$ (see 'Results'), calculated from instantaneous CTD transects conducted from 1997 to 2000. The 3 transects highlighted in Fig. 4 are marked by arrows. Vertical lines are 95\% CI on $r$ associated with vertical water-property variation. Estimated population growth rates $\mu_{\text {tot }}$ are also given. (b-d) Vertically integrated primary production, nitrate concentration, and production:biomass ratio $(P: B)$ at Bay Center and Naselle. Each point in (b) to (d) represents water samples taken within $2 \mathrm{~d}$ of the transects in (a). The conversion to $\mu_{\text {growth }}$ for the broad range of C:chl ratio values of 10 to 100, is also shown in (d); precise $\mu_{\text {tot }}$ values cannot be determined from these data, but it can be concluded that

$$
\left|\mu_{\text {growth }}\right|>>\left|\mu_{\text {tot }}\right|
$$


relative to dilution along the entire estuary (e.g. September 1999, Figs. 4i \& 5a). Exceptions do occurduring strong upwelling, chlorophyll maxima within the estuary are possible (July 1999, Fig. 4h) - but widespread nitrate-depletion in summer (Fig. 5c) suggests that new nutrients are generally exhausted by the time incoming water reaches Bay Center, approximately 1 tidal excursion $(15 \mathrm{~km})$ from the mouth. The high primary production rates observed (Fig. 5b) thus appear to represent growth on regenerated, not newly imported, nutrients: the phytoplankton population is rapidly cycling, but slowly declining as a whole as it spreads into the estuary. In the next section, we examine the contribution of cultivated oysters and other benthic grazers to this population decline.

\section{Grazing and seasonal phytoplankton distribution}

The best-guess benthic filtration rate $\alpha_{\text {ITZ (empirical) }}=$ $2 \pm 1 \times 10^{-5} \mathrm{~m} \mathrm{~s}^{-1}$ (see 'Methods') is equivalent to 40 to $120 \mathrm{~cm}$ per tidal cycle, compared with a mean tidal amplitude of $120 \mathrm{~cm}$, suggesting that Willapa Bay's intertidal benthos is able to clear a large fraction of the water directly above it on every tide. However, how filtration in the intertidal zone relates to the bay-wide, seasonal-timescale chlorophyll distribution depends on the details of the tidal circulation as much as on $\alpha_{\text {ITZ }}$. As used in our model, $\alpha$ can be interpreted as 'the nonregenerated fraction of total benthic filtration,' the fraction corresponding to filter-feeder growth, biodeposition, or other long-term losses from the plankton. By varying $\alpha$ in the model and comparing the chlorophyll distributions that result with observations (Fig. 3), we can estimate what level of benthic grazing would be necessary to account for the along-channel phytoplankton population loss $\left(\mu_{\mathrm{tot}}\right)$ described in the previous section.

Results from 4 model scenarios are given in Fig. 6. In each of these scenarios, a constant oceanic chlorophyll concentration was imposed at the offshore open boundary (Fig. 1), a choice of $\alpha_{\mathrm{ITZ}}$ imposed, and the tidal model run for $60 \mathrm{~d}$. The filtration rate $\alpha_{\text {ITZ }}$ was only applied from $1.5 \mathrm{~m}$ below mean sea level (MSL) to $0.6 \mathrm{~m}$ above MSL: at higher elevations, oysters are not covered with water long enough to grow well (Ruesink et al. 2003). Over the course of each of these runs, the tidally averaged phytoplankton distribution asymptotically tends toward a steady-state balance between tidal import and grazing (Eq. 3). The run length of $60 \mathrm{~d}$ is approximately twice the average estuarine residence time and longer than the highest point-by-point water ages seen within the bay (Fig. 2). Accordingly, by the end of these runs the phytoplankton distribution has adjusted to within a few percent of its ultimate

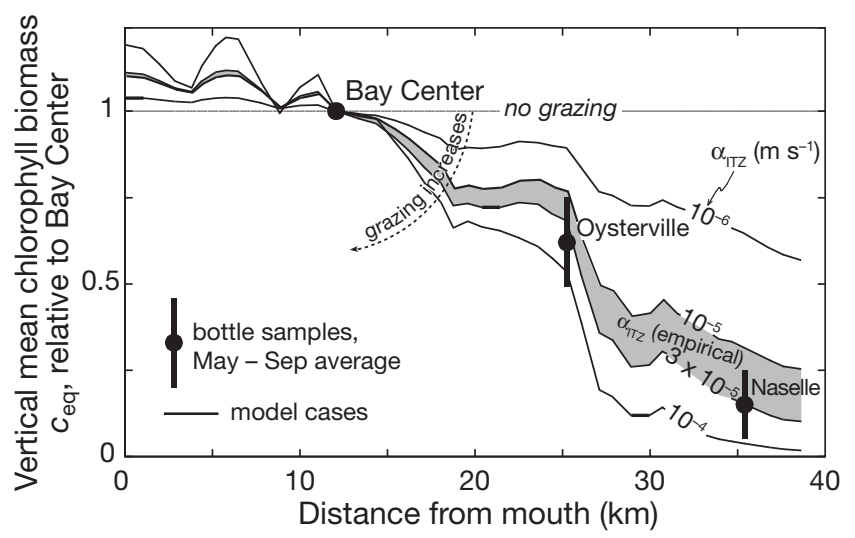

Fig. 6. Along-channel profiles of vertical-mean biomass concentration, relative to Bay Center, for a range of steady-state model scenarios (lines). Dots and bars give May-September means and $95 \%$ CI at time-series stations (see Fig. 3). Each line represents a particular value of the intertidal benthic grazing rate. Shaded range indicates uncertainty in the empirical grazing rate. ITZ: intertidal zone

equilibrium value. We refer to the horizontal phytoplankton field after $60 \mathrm{~d}$ of adjustment, averaged vertically and over the tidal cycle, as $C_{\text {eq. }}$. The results shown in Fig. 6 are $c_{\text {eq }}$ along the main axis of Stanley Channel, relative to $C_{\text {eq }}$ at Bay Center. In addition, the full horizontal chlorophyll field for the $\alpha_{\text {ITZ(empirical) }}$ case is shown at 4 points in the tidal cycle in Fig. $7: c_{\text {eq }}$ is the time average over this cycle.

As the imposed grazing rate is increased, the alongestuary gradient in chlorophyll steepens: oceanic biomass penetrates a shorter distance into the estuary before being grazed down. The key observational benchmark for evaluating these model scenarios is the seasonal along-estuary chlorophyll gradient from bottle samples shown in Fig. 3 and re-plotted in Fig. 6. Mean depth at each station is $10 \pm 1 \mathrm{~m}$, and so depthaveraged $C$ (Fig. 6) and depth-integrated $B$ (Fig. 3) are proportional. (While true at these stations, this is not true in general: depth along Stanley Channel varies by a factor of 2).

The key result is that the $\alpha_{\text {ITZ }}$ runs that correspond to the uncertainty bounds on $\alpha_{\text {ITZ (empirical) }}$ (Fig. 6 , shaded region) coincide closely with observations. There is no significant difference between the along-estuary chlorophyll decline actually observed in Willapa Bay and the along-estuary chlorophyll decline one would predict, using this model, from empirical estimates of oyster filtration. Furthermore, adjusting observed chlorophyll-biomass values using predicted variation in the C:chl ratio (see 'Methods') would not change this conclusion. The uncertainty in this analysis is broad, however. Confidence limits on observed chlorophyll correspond to an uncertainty in $\alpha_{\text {ITZ (empirical) }}$ of a factor of 3 at Naselle and close to an order of magnitude at 


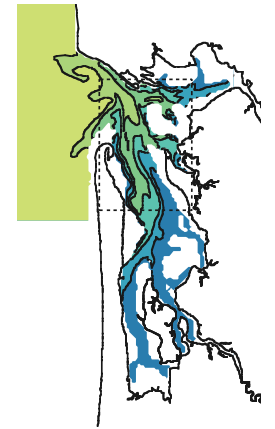

low slack

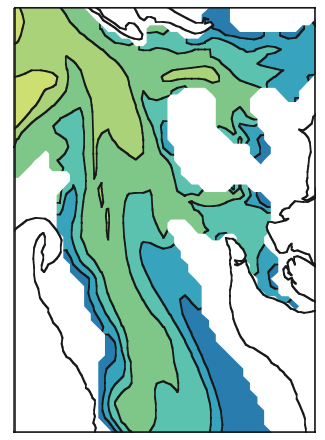

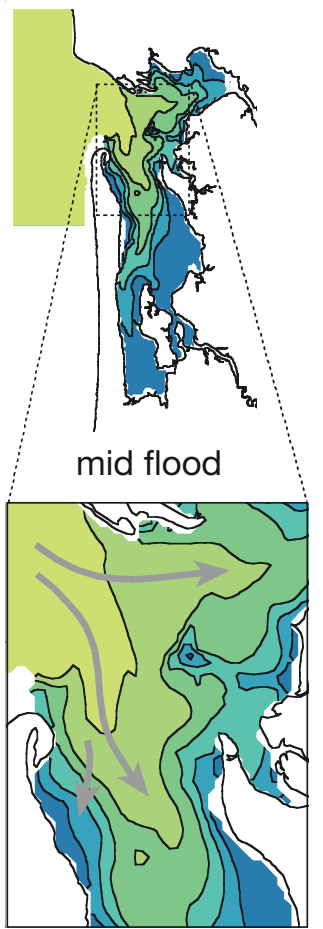

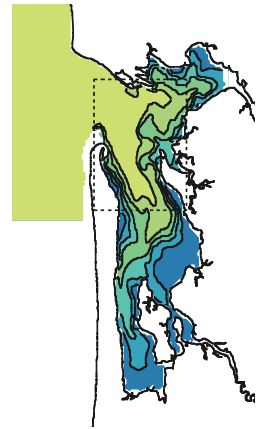

high slack

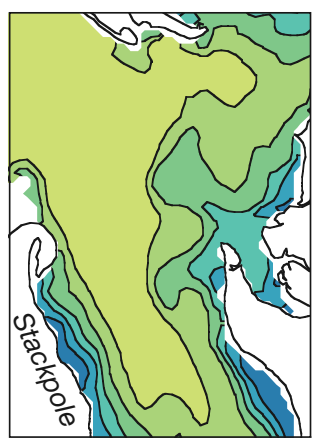

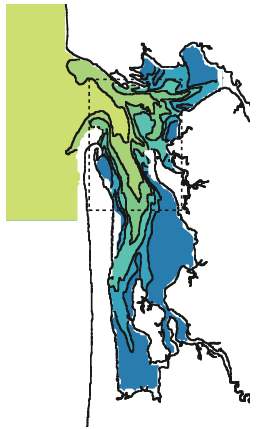

mid ebb

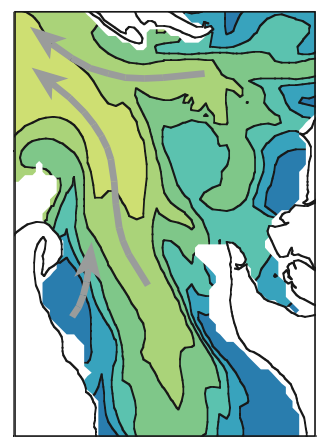

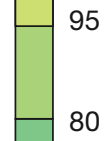

ن

要

60

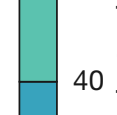

40

응

20

¿

Fig. 7. Model results showing depth-averaged phytoplankton concentration over 1 tidal cycle after $60 \mathrm{~d}$ of adjustment. Tidal import of a constant oceanic concentration is the only source; intertidal benthic grazing, at the best-guess empirical rate $2 \times 10^{-5}$ $\mathrm{m} \mathrm{s}^{-1}$, is the only sink. Gray arrows indicate transport at times of maximum tidal velocity

Oysterville. This 3- to 10-fold uncertainty is probably inevitable without a data set and modeling approach that better resolve event-scale fluctuations and planktonic interactions.

Despite this uncertainty, we can conclude that benthic grazing is a first-order contributor to the nearly 10 -fold decline in summer phytoplankton biomass from Willapa Bay's mouth to the head at Naselle. In fact, it appears that the draw-down associated with cultivated oysters alone (lower bound on $\alpha_{\text {ITZ (empirical) }}$ ) is by itself a first-order component of the seasonal phytoplankton budget.

\section{Food competition and carrying capacity}

The nearly monotonic up-estuary decline in chlorophyll $C_{\text {eq }}$ (Fig. 6) suggests that food availability at Naselle and the rest of the inner (southern) estuary is largely controlled 'remotely'; that is, not by local (10 to $1000 \mathrm{~m}$ scale) growth and grazing conditions, but by the $40 \mathrm{~km}$ gauntlet of filterers that any oceanic water parcel must run before reaching the southern bay. Indeed, when we vary $\alpha_{\text {ITZ }}$ in the outer and inner estuary independently (Fig. 8), food concentration in the inner estuary turns out to be far more sensitive to grazing in the outer bay than grazing locally. When grazing is applied in the model north of the fattening line only (see 'Introduction'), phytoplankton concentration in Shoalwater Bay varies with grazing rate almost as steeply as when grazing is applied north and south of the line alike. Even the contribution of cultivated oysters alone (low estimate of $\alpha_{\text {ITZ (empirical) }}=1 \times$ $10^{-5} \mathrm{~m} \mathrm{~s}^{-1}$ ), imposed north of the fattening line only, is enough to reduce food concentration in Shoalwater Bay to $35 \%$ of the oceanic source. (In the absence of grazing, tidal advection over the $60 \mathrm{~d}$ model run would raise Shoalwater Bay food concentration, which starts at 0 , to $70 \%$ oceanic.) Furthermore, when grazing north of the fattening line is held constant, increasing grazing south of the line from 0 to $10^{-4} \mathrm{~m} \mathrm{~s}^{-1}$, well

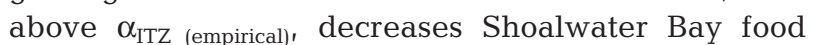
concentration by only one-third.

This level of food competition on the whole-estuary scale implies that Willapa Bay is within a small factor of its 'bivalve carrying capacity.' Dame \& Prins (1998) show that carrying capacity can be estimated by comparing the system-wide flushing rate, bivalve clearance rate, and (in systems where local phytoplankton growth exceeds import) primary production rate. The total filtration capacity associated with $\alpha_{\text {ITZ (empirical) }}$ i.e. $\alpha_{\text {ITZ (empirical) }}$ multiplied by the area of the intertidal zone - is 1300 to $4000 \mathrm{~m}^{3} \mathrm{~s}^{-1}$, or 1 bay volume in 2 to $7 \mathrm{~d}$. The net tidal exchange rate at the mouth (the frac- 
tion of each flood tidal prism that does not exit on the following ebb, divided by the length of the tidal cycle) is effectively the same value, $3000 \mathrm{~m}^{3} \mathrm{~s}^{-1}$ or 1 bay volume in $5 \mathrm{~d}$ (Banas et al. 2004). This correspondence of flushing and filtration timescales means that if incoming ocean water were mixed intantaneously throughout the bay, and made completely and uniformly available to the benthos, intertidal grazers could deplete the oceanic food supply as quickly as it arrived.

Food availability for bivalves is not always controlled at the system level, however. Even in systems far below their overall bivalve carrying capacity, bivalve growth rates may be controlled by local depletion and the small-scale details of the circulation (Pitcher \& Calder 1998). Progressive depletion of phytoplankton advected across benthic grazers can create strong food-concentration gradients on scales from several km (Norén et al. 1999, Tweddle et al. 2005) down to just a few meters (Newell 1990). Indeed, the $\alpha_{\text {ITZ (empirical) model }}$ run depicted in Fig. 7 shows concentration variations across 1 to $2 \mathrm{~km}$-wide banks (e.g. near the Stackpole fattening-bed area) that are comparable with the along-channel variation over $10 \mathrm{~s}$ of $\mathrm{km}$.

Progressive depletion by grazers is not the only explanation of such variations. Vertical elevation, and hence the time each patch of grazers spends out of the water and the volume of water overhead each patch to be cleared, could also be responsible. Even in the absence of grazing, 'differential advection,' arising from gradients in the strength of tidal currents, can create cross-bank temperature and salinity variations up to $5^{\circ} \mathrm{C}$ and 4 psu in Willapa Bay (Hickey \& Banas 2003; see also Huzzey \& Brubaker 1988, O'Donnell 1993). This is the mechanism responsible for the strong channel-to-shore gradients in water age seen in the Hickey \& Banas (2005) tidal model (Fig. 2).

Thus both the local distribution of grazers and the local structure of tidal currents can create dramatic small-scale controls on food availability and drawdown. How, then, can we analyze carrying capacity in the bay-wide sense, if not through bay-wide rates and timescales like the $3000 \mathrm{~m}^{3} \mathrm{~s}^{-1}$ mentioned above? Furthermore, if food availability is controlled not just by the circulation but by the consumers themselves, how can we address carrying capacity without a full hydrodynamic-plus-ecosystem-plus-physiological model, of the kind reviewed by Smaal et al. (1998)?

The resolution lies in the fact that the grazing term in Eq. (3) couples consumers $(\alpha)$ to producers $(c)$, much as in a Lotka-Volterra predator-prey balance (compare Officer et al. 1982). As benthic biomass increases, filtration rate $\alpha$ increases and the penetration of phytoplankton biomass $c$ into the estuary shortens (Fig. 6); but as $C$ drops at a given location, the food intake rate $\langle\alpha c\rangle$ also drops. To the extent that $\alpha$ is proportional to filter-fee-

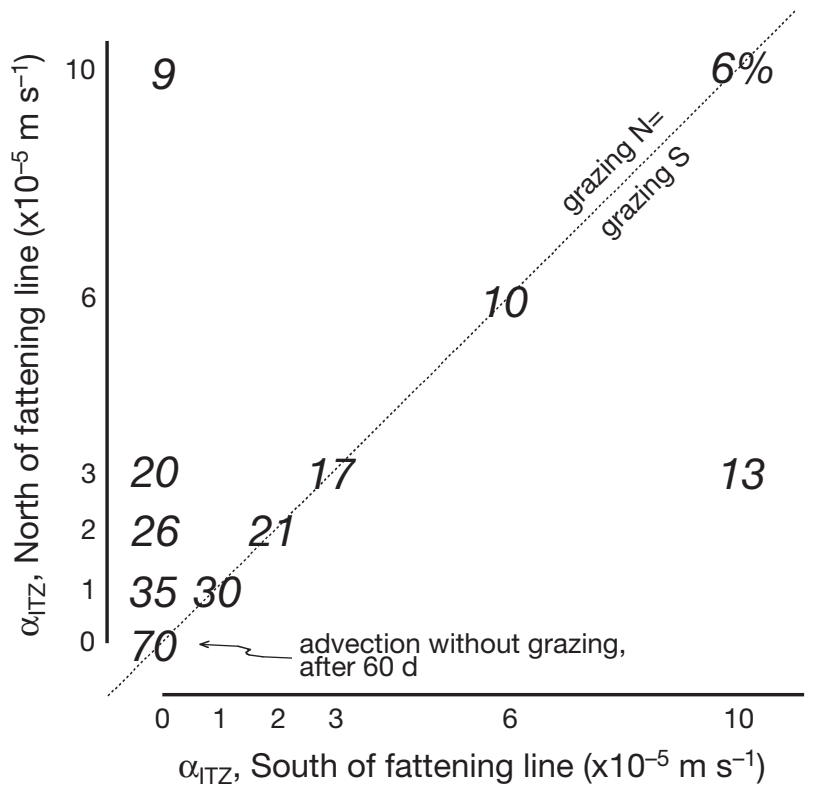

Fig. 8. Steady-state phytoplankton concentration in Shoalwater Bay as a \% of concentration in steady oceanic supply, for a variety of combinations of outer-estuary (north of fattening line; see Fig. 1) and inner-estuary (south of fattening line) intertidal benthic grazing rates. Diagonal dotted line marks the cases in which grazing is spatially uniform, as in Fig. 6

der standing stock, and food intake $\langle\alpha c\rangle$ is proportional to new filter-feeder growth (Powell et al. 1992, Kobayashi et al. 1997, Grant et al. 1993), examining baytotal benthic food intake as a function of $\alpha$ can tell us the degree to which a given filter-feeder standing stock limits its own growth through food competition.

Bay-total intake is shown in Fig. 9 for runs spanning a 20 -fold variation in filtration rate $\alpha$. The model gives food intake as a volume flux $\left(\mathrm{m}^{3} \mathrm{~s}^{-1}\right)$ times the imposed oceanic food concentration; it thus can be expressed as a fraction of the net tidal supply rate $\left(3000 \mathrm{~m}^{3} \mathrm{~s}^{-1}\right)$ discussed above. To express intake in the more meaningful (but approximate) units of $\mathrm{kg} \mathrm{chl} \mathrm{h}{ }^{-1}$, we assumed a mean oceanic chlorophyll concentration of $10 \mathrm{mg} \mathrm{chl} \mathrm{m}^{-3}$, close to the summer average at Bay Center. For the runs corresponding to $\alpha_{\text {ITZ (empirical), bay-total intake is } 10 \text { to } 20 \mathrm{~kg}}$ chl h${ }^{-1}$, or 8 to $15 \%$ of the net tidal supply. This small fraction indicates that most of the oceanic chlorophyll that the tidal-residual circulation advects into the estuary eventually is advected back out without being consumed. In other words, although within the bounds of the bay, most of that chlorophyll is not actually available to sessile, intertidal organisms: it is presumably trapped in the main channels, withheld from intertidal grazers by a lack of tidal dispersion on small scales.

There is no abrupt point of carrying capacity at which intake stops increasing with $\alpha$, but as $\alpha$ in-

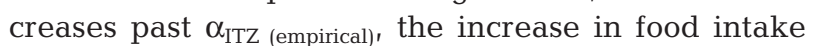
slows. If food availability were not affected by draw- 


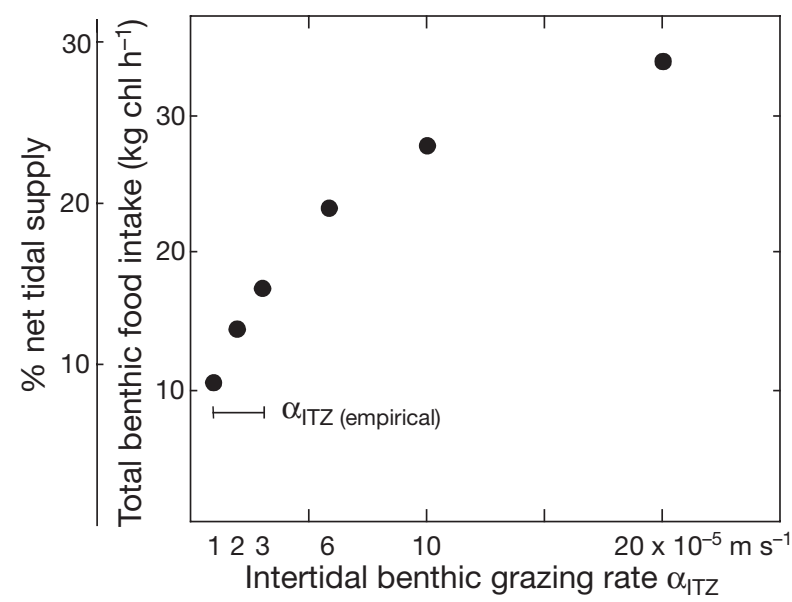

Fig. 9. Total food intake by the benthos (given as both phytoplankton weight per unit time, and as a \% of the flood-ebb net tidal supply at the mouth) as a function of intertidal benthic grazing rate

down, the intake-filtration relationship would be linear, so that population growth kept pace with biomass and specific, individual growth rate was unaffected. The intake-filtration rate is in fact far below linear. Doubling $\alpha$ from $10^{-5} \mathrm{~m} \mathrm{~s}^{-1}$ to $2 \times 10^{-5} \mathrm{~m} \mathrm{~s}^{-1}$ only increases total food intake by a factor of 1.4 , not 2 . Further increasing filtration rate by a factor of 10 only increases food intake by a factor of 2, not 10 . Thus, despite the fact that only a small fraction of the oceanic food supply is consumed within the bay, Willapa Bay appears to lie in a regime where further increase in the population of benthic grazers would reduce the specific food-intake rate ( $\mathrm{g}$ phytoplankton $\mathrm{kg}^{-1}$ grazer $\mathrm{d}^{-1}$ ) within that same population.

\section{DISCUSSION}

\section{Sources of new primary production: Willapa Bay in context}

The key results from the observational analysis above can best be summarized by comparison with 2 other systems: South San Francisco Bay (SSFB) and Saldhana Bay, South Africa. Primary production in SSFB has been as well-studied as in any estuary, as Cloern (1996) reviewed; furthermore, SSFB lies on the same coast as Willapa Bay, is similar in size and morphology (Hickey \& Banas 2003), and has a similar seasonal riverflow pattern (Conomos et al. 1985). Saldhana Bay is notable for being, like Willapa Bay, an ocean-dominated, upwelling-fueled ecosystem with active bivalve aquaculture (Grant et al. 1998). Nevertheless, we found that the dynamics of primary production in Willapa Bay contrast sharply with both systems.
SSFB, like Willapa Bay, is generally vertically wellmixed in summer (Conomos et al. 1985). Nevertheless, in contrast to Willapa Bay, phytoplankton blooms in SSFB (as in many estuaries) are supported by terrestrial nutrients and tightly controlled by stratification dynamics, on spring-neap, seasonal, and interannual timescales (Cloern 1991, 1996). Lateral tidal dispersion is weaker in SSFB than in Willapa Bay (Gross et al. 1999), and so the primary biological effect of tidal mixing there is to erase stratification and inhibit blooms (Cloern 1996). In contrast, in Willapa Bay, increased tidal mixing means increased horizontal exchange (Banas et al. 2004) and thus increased import of oceanic phytoplankton.

Primary production in Saldhana Bay, as in Willapa Bay, derives from coastal upwelling; accordingly, in both estuaries, chlorophyll is high near the mouth and lower up-estuary (Fig. 3; Pitcher \& Calder 1998). This chlorophyll pattern is opposite to that in SSFB and the majority of terrestrial-nutrient-fueled estuaries: in Willapa and Saldhana Bays, ocean-estuary exchange is a source of new production, not a sink. Nevertheless, the physical mechanism of ocean-estuary exchange differs between Willapa and Saldhana Bay, and this creates a fundamental difference in their primary production budgets. In Saldhana Bay, ocean-estuary coupling is primarily baroclinic: the influx of a dense, upwelled water mass at depth is balanced by outflow in the surface layer (Monteiro et al. 1998, Monteiro \& Largier 1999). In Willapa Bay, as discussed, exchange with the ocean is primarily tidal and barotropic. New ocean water enters the bay at all depths; baroclinic effects may retard the influx of ocean water in the surface layer, but in general do not actually reverse it (Hickey et al. 2002). The biological consequence is that during upwelling conditions in Saldhana Bay, nutrients are imported at depth, but oceanic phytoplankton in the surface layer are not imported (Monteiro et al. 1998) as they are in Willapa Bay. Summer production in Saldhana is controlled by tidal and wind mixing, which draw nutrients into the otherwise nutrient-depleted surface layer (Pitcher \& Calder 1998). In sharp contrast, Willapa Bay's biggest source of new production is horizontal import of the new production that has already occurred offshore or near the mouth. There are almost no new nutrients left to resuspend more than a tidal excursion (15 km) into the bay (Fig. 5), and the bay's phytoplankton population, while still growing rapidly on regenerated nutrients, declines as a whole.

\section{From phytoplankton to oyster growth}

In Willapa Bay, as shown in Fig. 5, primary productivity is high throughout the summer: this is another 
feature shared with upwelling-fueled Saldhana Bay (Pitcher \& Calder 1998). In contrast, in SSFB, phytoplankton biomass and productivity are low in summer


1982), less than $500 \mathrm{mg} \mathrm{C} \mathrm{m}^{-2} \mathrm{~d}^{-1}$ (Cloern 1996) - and in general only escape this range during the spring bloom. Part of this contrast between Willapa Bay and SSFB is circulational and nutrient- and light-driven, as discussed above. Another difference may be the severity of control by benthic grazing. Despite the fact that its grazers are mainly uncultivated, Cloern (1982) writes that SSFB 'behaves like a large aquaculture system...where sewage-derived wastes are converted to algal biomass and then molluscan biomass'. He calculates a population filtration rate of $\sim 10^{-4} \mathrm{~m} \mathrm{~s}^{-1}(9 \mathrm{~m}$ $\mathrm{d}^{-1}$ ), similar to that reported by Tweddle et al. (2005) for mussels in Menai Strait, but 3 to $10 \times$ higher than the $\alpha_{\text {ITZ (empirical) }}$ that we determined for Willapa Bay above. This level of benthic filtration is enough to clear the volume of SSFB 1.2 to $1.8 \times$ daily (Cloern 1982).

In our analysis, Willapa Bay could likewise be described as 'a large aquaculture system', but since the primary input is not a nutrient load but phytoplankton biomass itself, an even simpler analogy is 'a large oyster': a filter feeder that uses tidal-residual currents to clear 250 to $500 \mathrm{~m}^{3} \mathrm{~s}^{-1}$ from the Washington shelf ecosystem (Fig. 9). This value is only 8 to $15 \%$ of the mean volume flux associated with tidal ocean-estuary exchange (3000 $\mathrm{m}^{3} \mathrm{~s}^{-1}$; Banas et al. 2004). Thus, Willapa Bay converts only a small fraction of its total external food supply into new bivalve growth and returns the rest to the coastal ocean, despite the fact that food competition within the bay is widespread (Figs. 8 \& 9). This indicates that for a 'filter feeder' the size of Willapa Bay, not just its total hydrodynamic 'intake' at the mouth but the details of its 'digestion' — the internal map of advective pathways in relation to sites of drawdown-determine the amount of food available for new bivalve growth.

As noted in the 'Introduction' and discussed more fully by Hedgpeth \& Obrebski (1981), it has long been suspected in the Willapa Bay oyster community that commercial oysters in the mid- to outer (northern) estuary were in competition for food with commercial and feral oysters in the inner (southern) estuary. Competitive controls on food availability have been suggested in both directions, north limiting south and south limiting north (Hedgpeth \& Obrebski 1981). From our model analysis it appears unlikely that filter feeders south of the fattening/recruitment line could have a significant effect on food supply north of the line, but food-limitation in the other direction appears to be severe: we estimate that grazing north of the line reduces the seasonal supply of oceanic phytoplankton to Shoalwater Bay by half (Fig. 8).
Another long-held suspicion (Hedgpeth \& Obrebski 1981), not obviously reconcilable with the idea of widespread food competition, is that it should nevertheless be possible to increase the level of commercial oyster production in Willapa Bay. Our model results suggest that this may be so, but with diminishing returns. Planting more filter feeders (increasing $\alpha$ ) would increase total food intake by the benthos (a proxy for filter feeder growth), but would decrease specific or individual food intake (Fig. 9). Thus, model results are compatible with larger harvests and longer times to maturity, or with smaller harvests and shorter times to maturity, at a given level of oceanic food supply.

\section{CONCLUSIONS}

Time-series observations (Newton \& Horner 2003, this study) have shown that phytoplankton biomass and production in Willapa Bay have strong spatial gradients in summer, high near the mouth and low in the interior. This pattern is similar to that in another upwelling-fueled estuary, Saldhana Bay, but reflects a different coupling to the coastal ocean. As upwelled coastal water is stirred into Willapa Bay by the tides, nutrients are rapidly depleted and over most of the estuary phytoplankton biomass as a whole declines, even as growth on regenerated nutrients remain high. This indicates a net transfer of phytoplankton from the coastal ocean to the estuary, not the reverse, in the long-term summer average.

Experiments with a non-conservative tracer in a spatially detailed circulation model suggest that Willapa Bay's intertidal benthic grazers have the filtration capacity to account for most of the loss of phytoplankton biomass observed. Cultivated Pacific oysters by themselves are likely to be a first-order loss term in the bay's phytoplankton budget. In the model, phytoplankton consumption by oysters in the outer bay severely limits food availability for oysters in the upper bay, where lower growth rates have long been observed (Chapman \& Esveldt 1943, Ruesink et al. 2003). In fact, Willapa Bay's oysters appear to be within a small factor of their carrying capacity, in the sense that any large increase in the density of intertidal grazers above current levels is predicted to decrease the food intake per individual. ('Within a small factor of' is not the same as 'at': this is, like our other model results, an order-of-magnitude assessment.)

Nevertheless, it appears that the tidal circulation is an equally stringent control on food availability in the intertidal zone. Despite the benthos' high clearance rates, the model predicts that most of the oceanic phytoplankton that enter the bay eventually are flushed out again without spending enough time over 
intertidal areas to be grazed. Of the phytoplankton that remain in the bay longer than 1 tidal cycle (i.e. the net tidal supply, $30 \%$ of the total flood-tide supply), the intertidal benthos captures only 8 to $15 \%$. The tidal dynamics that create this limitation are small-scale, local, and poorly understood. Still, this model result indicates that it may be an order-of-magnitude error to assume that any phytoplankton found within the bounds of an estuary-even an estuary with a tidal prism $50 \%$ of its volume-are hydrodynamically available to intertidal organisms.

To make more specific predictions for particular aquaculture management scenarios, a future model will require a better representation of planktonic interactions and bivalve physiology (Kobayashi et al. 1997, Smaal et al. 1998), as well as some representation of food sources for oysters other than phytoplankton in the northern bay (Ruesink et al. 2003). However, our results suggest that refining the treatment of the tidal circulation, using a higher-resolution grid and detailed, comprehensive maps of intertidal subtrate and bathymetry, may be just as important as refining the treatment of the ecosystem. We found that even in an estuary as apparently well-flushed as Willapa Bay, an ecologically simple but hydrodynamically detailed model can reveal controls on secondary production that system-wide averages would not.

Acknowledgements. This study was supported by grants NA76 RG0119 Project R/ES-9, NA76 RG0119 AM08 Project R/ES-33, NA16 RG1044 Project R/ES-42, NA76 RG0485 Project R/R-1 and NA96 OP0238 Project R/R-1 from the NOAA to the Washington Sea-Grant Program, University of Washington, and Grant CR 824472-01-0 from the United States Environmental Protection Agency. At the Washington Department of Ecology, Eric Siegel, Katherine Cox, and Judah Goldberg were responsible for initial data processing. Many thanks to Brett Dumbauld and the Washington Department of Fish and Wildlife, who generously provided boat time, field support, and invaluable information on oyster cultivation patterns. Conversations with Alan Trimble, Ted de Witt, and Evelyn Lessard, as well as the suggestions of anonymous reviewers, were very helpful.

\section{LITERATURE CITED}

Banas NS (2005) Dynamics of Willapa Bay, Washington: links to the coastal ocean, tidal dispersion, and oyster carrying capacity. PhD dissertation, University of Washington, Seattle

Banas NS, Hickey BM (2005) Mapping exchange and residence time in a model of Willapa Bay, Washington, a branching, macrotidal estuary. J Geophys Res 110: C11011, doi:10.1029/2005JC002950

Banas NS, Hickey BM, MacCready P, Newton JA (2004) Dynamics of Willapa Bay, Washington: a highly unsteady, partially mixed estuary. J Phys Oceanogr 34:2413-2427

Batchelor GK (1967) An introduction to fluid dynamics. Cambridge University Press, Cambridge
Burchard H, Bolding K (2002) GETM, a general estuarine transport model: scientific documentation. Technical report. European Commission, Ispra

Burchard H, Bolding K, Villareal MR (2004) Three-dimensional modelling of estuarine turbidity maxima in a tidal estuary. Ocean Dyn 54:250-265

Burrowing Shrimp Committee (1992) Findings and recommendations and an integrated pest management plan for the control of burrowing shrimp on commercial oyster beds in Willapa Bay and Grays Harbor, Washington State. Report to Grays Harbor and Pacific County Commissioners, South Bend, WA (see http://uwashington.worldcat. org/oclc/50187814)

Calbet A, Landry MR (2004) Phytoplankton growth, microzooplankton grazing, and carbon cycling in marine systems. Limnol Oceanogr 49:51-57

Chapman WM, Esveldt GD (1943) The spawning and setting of the Pacific oyster (Ostrea gigas Thunberg). Biological Report 43A. Washington Department of Fisheries, Seattle

Cloern JE (1982) Does the benthos control phytoplankton biomass in south San Francisco Bay (USA)? Mar Ecol Prog Ser 9:191-202

Cloern JE (1991) Tidal stirring and phytoplankton bloom dynamics in an estuary. J Mar Res 49:203-221

Cloern JE (1996) Phytoplankton bloom dynamics in coastal ecosystems: a review with some general lessons from sustained investigation of San Francisco Bay. Rev Geophys 34:127-168

Cloern JE, Grenz C, Vidergar-Lucas L (1995) An empirical model of the phytoplankton chlorophyll/carbon ratio-the conversion factor between productivity and growth rate. Limnol Oceanogr 40:1313-1321

Conomos TJ, Smith RE, Gartner JW (1985) Environmental setting of San Francisco Bay. Hydrobiologia 129:1-12

Dame RF, Prins TC (1998) Bivalve carrying capacity in coastal ecosystems. Aquat Ecol 31:409-421

Dumbauld BR (1994) Thalassinid shrimp ecology and the use of carbaryl to control populations on oyster ground in Washington coastal estuaries. PhD dissertation, University of Washington, Seattle

Dumbauld BR, Armstrong DA, Feldman KL (1996) Lifehistory characteristics of two sympatric thalassinidean shrimps, Neotrypea californiensis and Upogebia pugettensis with implications for oyster culture. J Crustac Biol 16:689-708

Ebbesmeyer CC, Strickland RM (1995) Oyster condition and climate: evidence from Willapa Bay. Publication WSG-MR 95-02. Washington Sea Grant, Seattle

Evans GT, Parslow JS (1985) A model of annual plankton cycles. Biol Oceanogr 3:327-347

Falkowski PG, Raven JA (1997) Aquatic photosynthesis. Blackwell Science, Malden, MA

Feldman KL, Armstrong DA, Dumbauld BR, DeWitt TH, Doty DC (2000) Oysters, crabs, and burrowing shrimp: review of an environmental conflict over aquatic resources and pesticide use in Washington state's (USA) coastal estuaries. Estuaries 23:141-176

Francis R (2003) A web of small tensions. Fisheries 28:20-23

Grant J, Dowd M, Thompson K, Emerson C, Hatcher A (1993) Perspectives on field studies and related biological models of bivalve growth. In: Dame RF (ed) Bivalve filter feeders and marine ecosystem processes. Springer-Verlag, New York, p 371-420

Grant J, Stenton-Dozey J, Monteiro P, Pitcher G, Heasman K (1998) Shellfish culture in the Benguela system: a carbon budget of Saldhana Bay for raft culture of Mytilus galloprovincialis. J Shellfish Res 17:41-49 
Griffen BD, DeWitt TH, Langdon C (2004) Particle removal rates by the mud shrimp Upogebia pugettensis, its burrow, a commensal clam: effects on estuarine phytoplankton abundance. Mar Ecol Prog Ser 269:223-236

Gross ES, Koseff JR, Monismith SG (1999) Evaluation of advective schemes for estuarine salinity simulations. J Hydraul Engin 125:32-46

Hansen DV, Rattray M Jr (1966) New dimensions in estuary classification. Limnol Oceanogr 11:319-326

Hedgpeth JW, Obrebski S (1981) Willapa Bay: a historical perspective and a rationale for research. FWS/OBS-81/03. US Fish and Wildlife Service, Washington, DC

Heip CHR, Goosen NK, Herman PMJ, Kromkamp J, Middelburg JJ, Soetaert K (1995) Production and consumption of biological particles in temperate tidal estuaries. Oceanogr Mar Biol Annu Rev 33:1-149

Hickey BM (1989) Patterns and processes of circulation over the shelf and slope. In: Hickey BM, Landry MR (eds) Coastal oceanography of Washington and Oregon. Elsevier, New York, p 41-115

Hickey BM, Banas NS (2005) Oceanography of the U.S. Pacific Northwest coastal ocean and estuaries with application to coastal ecology. Estuaries 26:1010-1031

Hickey BM, Zhang X, Banas N (2002) Coupling between the California Current System and a coastal plain estuary in low riverflow conditions. J Geophys Res 107:3166, doi: 101029/1999JC000160

Huzzey LM, Brubaker JM (1988) The formation of longitudinal fronts in a coastal plain estuary. J Geophys Res 93: 1329-1334

Kobayashi M, Hofmann EE, Powell EN, Klinck JM, Kusaka K (1997) A population dynamics model for the Japanese oyster, Crassostrea gigas. Aquaculture 149:285-321

Kraus NC (2000) Study of navigation channel feasibility, Willapa Bay, Washington. Final Report. US Army Corps of Engineers Seattle District, Seattle

Landry MR, Hassett RP (1982) Estimating the grazing impact of marine micro-zooplankton. Mar Biol 67:283-288

Landry MR, Postel JR, Peterson WK, Newman J (1989) Broadscale distributional patterns of hydrographic variables on the Washington/Oregon shelf. In: Hickey BM, Landry MR (eds) Coastal oceanography of Washington and Oregon. Elsevier, New York, p 1-40

Lucas LV, Koseff JR, Cloern JE, Monismith SG, Thompson JK (1999) Processes governing phytoplankton blooms in estuaries. I: The local production-loss balance. Mar Ecol Prog Ser 187:1-15

Monteiro PMS, Largier JL (1999) Thermal stratification in Saldhana Bay (South Africa) and subtidal, density-driven exchange with the coastal waters of the Benguela upwelling system. Estuar Coast Shelf Sci 49:877-890

Monteiro PMS, Spolander B, Brundrit GB, Nelson G (1998) Shellfish culture in the Benguela system: estimates of nitrogen-driven new production in Saldhana Bay using two physical models. J Shellfish Res 17:3-13

Newell CR (1990) The effects of mussel (Mytilus edulis, Linnaeus, 1758) position in seeded bottom patches on growth at subtidal lease sites in Maine. J Shellfish Res 9:113-118

Newton JA, Horner RA (2003) Use of phytoplankton species indicators to track the origin of phytoplankton blooms in Willapa Bay, Washington. Estuaries 26:1071-1078

Norén F, Haamer J, Lindahl O (1999) Changes in the plankton

Editorial responsibility: Matthias Seaman (Assistant Editorin-Chief), Oldendorf/Luhe, Germany community passing a Mytilus edulis bed. Mar Ecol Prog Ser 191:187-194

O'Donnell J (1993) Surface fronts in estuaries: a review. Estuaries 16:12-39

Officer CB, Smayda TJ, Mann R (1982) Benthic filter feeding: a natural eutrophication control. Mar Ecol Prog Ser 9: 203-210

Peterson CH, Black R (1987) Resource depletion by active suspension feeders on tidal flats: influence of local density and tidal elevation. Limnol Oceanogr 32:143-166

Pitcher GC, Calder D (1998) Shellfish culture in the Benguela system: phytoplankton and the availability of food for commercial mussel farms in Saldhana Bay, South Africa. J Shellfish Res 17:15-24

Powell EN, Hofmann EE, Klinck JM, Ray SM (1992) Modeling oyster populations I. A commentary on filtration rate. Is faster always better? J Shellfish Res 11:387-398

Pritchard DW (1956) The dynamic structure of a coastal plain estuary. J Mar Res 15:33-42

Roegner GC, Shanks AL (2001) Import of coastally-derived chlorophyll a to South Slough, Oregon. Estuaries 24: $244-256$

Roegner GC, Hickey BM, Newton JA, Shanks AL, Armstrong DA (2002) Wind-induced plume and bloom intrusions into Willapa Bay, Washington. Limnol Oceanogr 47: 1033-1042

Ruesink JL, Roegner GC, Dumbauld BR, Newton JA, Armstrong DA (2003) Contributions of coastal and watershed energy sources to secondary production in a Northeastern Pacific estuary. Estuaries 26:1079-1093

Ruesink JL, Feist BE, Harvey CJ, Hong JS, Trimble AC, Wisehart LM (2006) Changes in productivity associated with four introduced species: ecosystem transformation of a 'pristine' estuary. Mar Ecol Prog Ser 311:203-215

Schoener A, Tufts DF (1987) Changes in oyster condition index with El Niño-Southern Oscillation events at $46^{\circ} \mathrm{N}$ in an eastern Pacific bay. J Geophys Res 92:14429-14435

Smaal AC, Prins TC, Dankers N, Ball B (1998) Minimum requirements for modelling bivalve carrying capacity. Aquat Ecol 31:423-428

Sonsangjinda $\mathrm{P}$, Matsuda $\mathrm{O}$, Yamamoto $\mathrm{T}$, Rajendran $\mathrm{N}$, Maeda H (2000) The role of suspended oyster culture on nitrogen cycle in Hiroshima Bay. J Oceanogr 56:223-231

Stanev E, Wolff JO, Burchard H, Bolding K, Flöser G (2003) On the circulation in the East Frisian Wadden Sea: numerical modeling and data analysis. Ocean Dyn 53:27-51

Stips A, Bolding K, Pohlmann T, Burchard H (2004) Simulating the temporal and spatial dynamics of the North Sea using the new model GETM (general estuarine transport model). Ocean Dyn 54:266-283

Strickland JD, Parsons TR (1968) A practical handbook of seawater analysis. Fish Res Board Can Bull 167

Tweddle JF, Simpson JH, Janzen CD (2005) Physical controls on food supply to benthic filter feeders in the Menai Strait. Mar Ecol Prog Ser 289:79-88

Whitney FA, Welch DW (2002) Impact of the 1997-8 El Niño and 1999 La Niña on nutrient supply in the Gulf of Alaska. Prog Oceanogr 54:405-421

Zimmerman JTF (1986) The tidal whirlpool: a review of horizontal dispersion by tidal and residual currents. Neth $\mathrm{J}$ Sea Res 20:133-154

Submitted: October 11, 2005; Accepted: December 12, 2006 Proofs received from author(s): June 13, 2007 